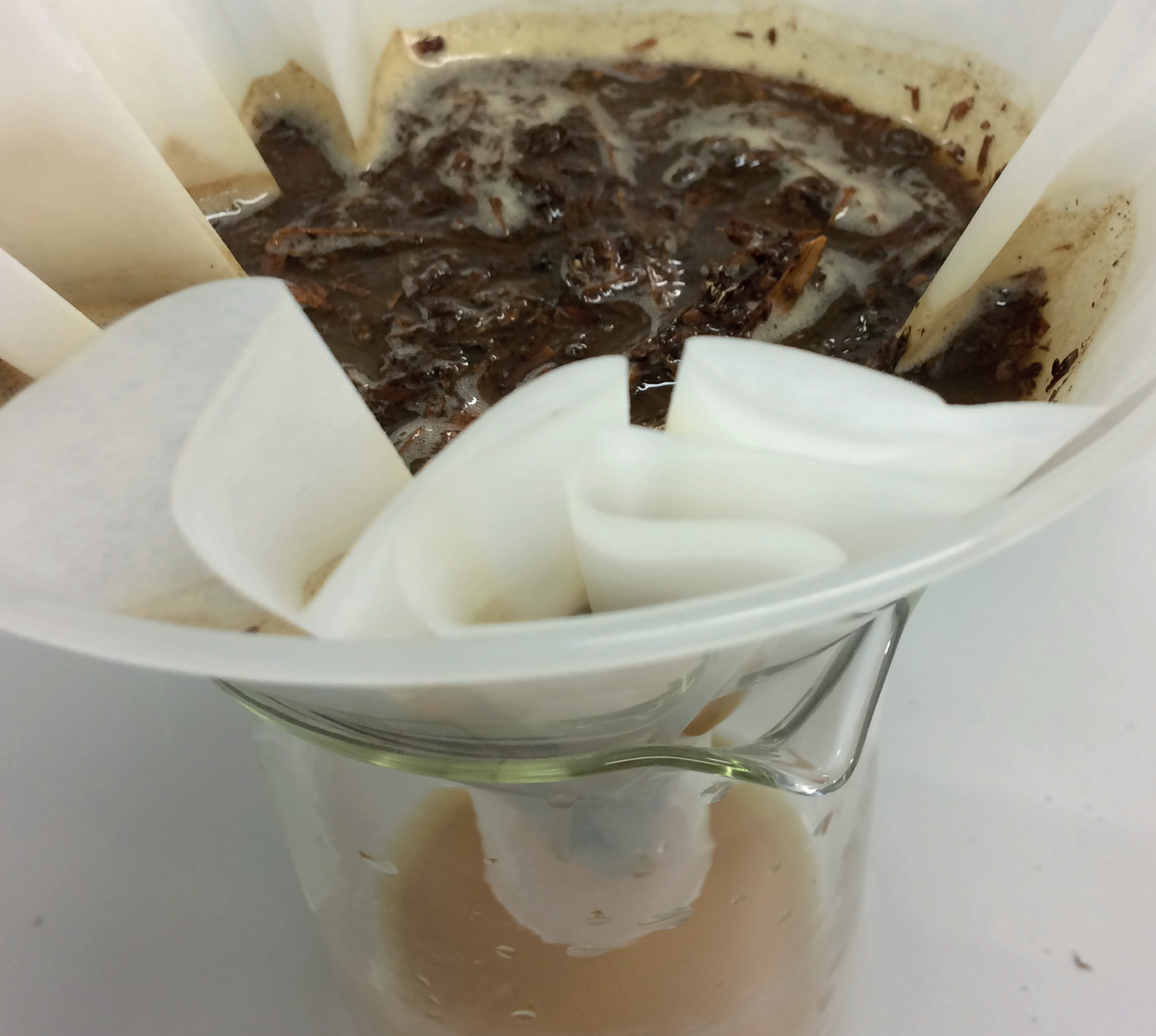

Growth of saltwater algae on press water of champost (spent mushroom waste)

Hellen Elissen, Saskia Gaastra \& Rommie van der Weide | Wageningen University \& Research | December 2020 


\section{Growth of saltwater algae on press water of champost (spent mushroom waste)}

Hellen Elissen, Saskia Gaastra \& Rommie van der Weide

This study was carried out by the Wageningen Research Foundation (WR), Business Unit Field Crops and was commissioned and financed by the PPP Biobased valorisation of manure and digestate AF-17052b. This project is financially supported by the Dutch Topsector Agri \& Food. Within the Topsector, private industry, knowledge institutes and the government are working together on innovations for safe and healthy food for 9 billion people in a resilient world. WR is part of Wageningen University \& Research, the collaboration of Wageningen University and Wageningen Research Foundation.

Wageningen, December 2020

Report WPR-829 
Elissen, H., S. Gaastra \& R. van der Weide, 2020. Growth of saltwater algae on press water of champost (spent mushroom waste). Wageningen Research, Report WPR-829. 24 pp; 3 fig.; 3 tab.; 10 ref., 3 annexes

This report can be downloaded for free at https://doi.org/10.18174/538586

Summary: For mushroom production usually a mixture of horse and chicken manure and straw is used. For every kg of mushrooms, $5 \mathrm{kgs}$ of waste is produced, a total of 800.000 tonnes per year in the Netherlands. Processing options are often either costly or complex. As the champost contains high salt concentrations, washing results in a solid (less salty) fraction with better re-use options and a nutrient-rich liquid fraction. On the latter fraction growth of five species of commercially relevant micro algae was tested in small-scale well tests. In addition, the press water was also treated with $\mathrm{H}_{2} \mathrm{O}_{2} / \mathrm{UV}$ to reduce the brown colour of the solution. In the majority of the triplicate well tests, growth of three of the five common saltwater algae species (Nannochloropsis gaditana, Porphyridium purpureum, and Tetraselmis chuii) on press water fractions of spent mushroom waste (champost) was found to be comparable to or better than their growth on control media. Dunaliella salina growth was relatively low. Arthrospira platensis only grew on press water when treated with $\mathrm{H}_{2} \mathrm{O}_{2}$. Overall, the results indicate that washing of champost results in a mineral rich solution suitable for growth of several (saltwater) algae.

Keywords: champost, spent mushroom waste, washing, press water, micro algae growth, decolourization

(C) 2020 Wageningen, Stichting Wageningen Research, Wageningen Plant Research, Business Unit Field Crops, P.O. Box 430, 8200 AK Lelystad, The Netherlands; T +31 (0)320 2911 11; www.wur.eu/plantresearch

Chamber of Commerce no. 09098104 at Arnhem

VAT NL no. 8065.11.618.B01

Stichting Wageningen Research. All rights reserved. No part of this publication may be reproduced, stored in an automated database, or transmitted, in any form or by any means, whether electronically, mechanically, through photocopying, recording or otherwise, without the prior written consent of the Stichting Wageningen Research.

Stichting Wageningen Research is not liable for any adverse consequences resulting from the use of data from this publication.

\section{Report WPR-829}

Photo cover: Saskia Gaastra 


\section{Contents}

$\begin{array}{ll}\text { Preface } & 5\end{array}$

$\begin{array}{ll}\text { Summary } & 7\end{array}$

1

$\begin{array}{ll}\text { Introduction } & 9\end{array}$

2

$\begin{array}{ll}\text { Materials and methods } & 11\end{array}$

$2.1 \quad$ Well test setup $\quad 11$

2.2 Press water 11

$\begin{array}{lll}2.3 & \text { Saltwater algae } & 12\end{array}$

$3 \quad$ Results and discussion $\quad 13$

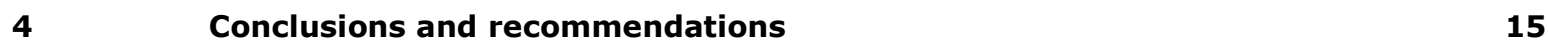

$\begin{array}{ll}\text { References } & 16\end{array}$

$\begin{array}{ll}\text { Annex } 1 \text { Compositions of champost } & 17\end{array}$

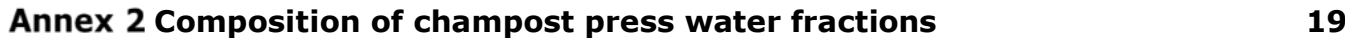

Annex 3 Pictures of well plates before and after the test ( 7 days) 22 



\section{Preface}

In the Netherlands, there are surpluses of manure and digestates/biogas slurries (digested manure and residual flows), which represent a negative value. At the same time, these residual flows contain valuable ingredients for the production of biomass (as raw material for food and feed products), for improving soil quality and for energy production. The number of feasible business cases in which the residual flow is upgraded has so far been limited. This is due both to the efficiency of the technologies used and the legislation and regulations related to the residual flows.

Recent information from research, scientific literature and companies provides new starting points for a biobased valorisation of manure/digestate streams and improving the efficiency of anaerobic digestion. The innovative aspect of our research is the cultivation of new types of biomass on the residual flows and the use of the conversion products to improve anaerobic digestion. This involves the use of separated manure and digestate products for the cultivation of mushrooms/fungi, worms, insects, specific bacteria and aquatic biomass. The resulting biomass can be further refined and marketed as food, feed and bio-based feedstock. There are also processed manure and digestate products that are valuable as fertilizer products for soil and plant growth, as substrate for improvement of anaerobic digestion or for export/use besides in agriculture. This gives a new interpretation to obligatory manure processing.

The aim of this project is to further explore and substantiate/test these ideas on lab and practical scale, leading to a proof of principles for new bio-based upgrading methods for manure and digestate that can be used in conjunction to better close cycles and/or sell outside regular agriculture.

Bottlenecks in legislation and regulations are explored and put on the agenda. Key figures are also calculated that are necessary for assessing sustainability (e.g. costs, environmental effects) and for supporting legislation (e.g. minerals, food safety).

The livestock sector gains insight into the possibilities of biobased valorisation and better marketing of their most important residual flows. For the small and medium-sized enterprises (SMEs) involved, this research provides proof of principle for their technology and input in their business cases. The combined effects of the technologies provide new knowledge, methods and research directions for science. In a social context, the use and upgrading of manure and digestates in other ways also contributes to the transition to a circular bio-economy with an efficient and sustainable agri-food sector.

More information:

- http://www.acrres.nl/en/projecten_acrres/biobased-valorization-of-manure-and-digestate/

- Rommie van der Weide: rommie.vanderweide@wur.nl, +31320291631

- Hellen Elissen: hellen.elissen@wur.nl, +31320291223

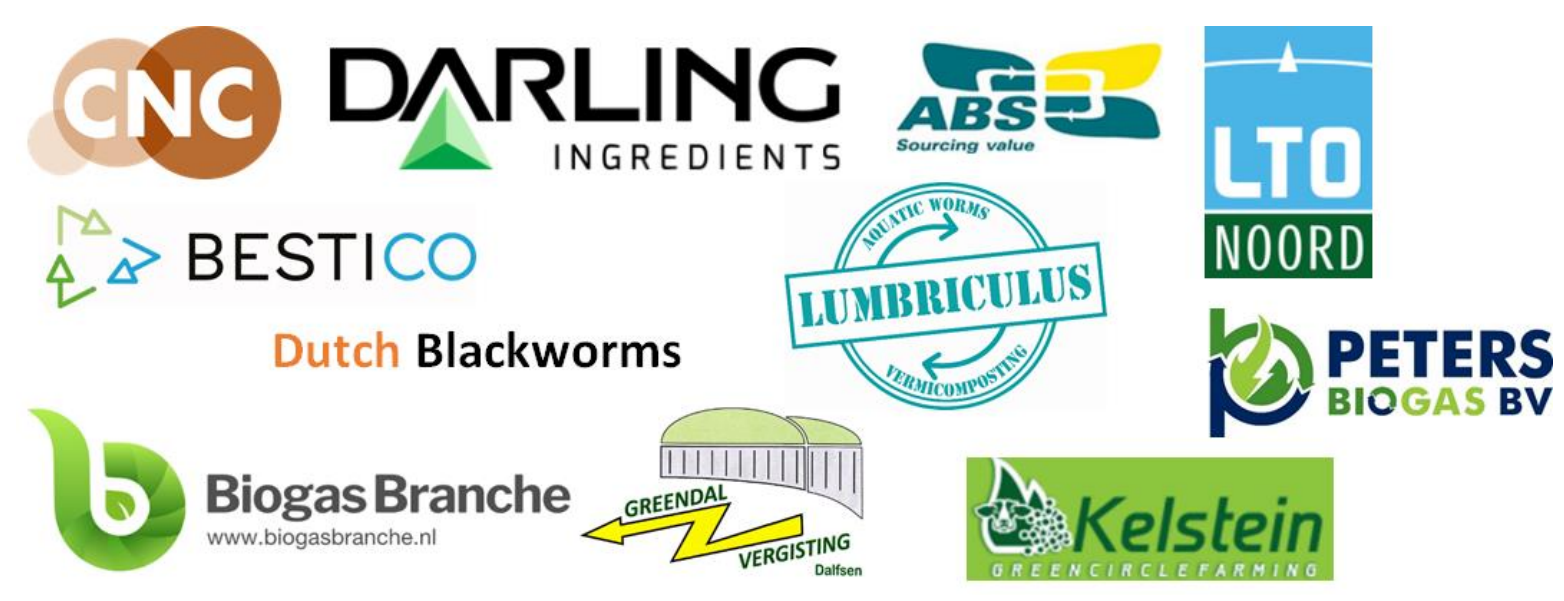




\section{Summary}

For mushroom production usually a mixture of horse and chicken manure and straw is used. For every $\mathrm{kg}$ of mushrooms, $5 \mathrm{kgs}$ of waste is produced, a total of 800.000 tonnes per year in the Netherlands. Processing options are often either costly or complex. As the champost contains high salt concentrations, washing results in a solid (less salty) fraction with better re-use options and a nutrient-rich liquid fraction. On the latter fraction growth of five species of commercially relevant micro algae was tested in small-scale well tests. In addition, the press water was also treated with $\mathrm{H}_{2} \mathrm{O}_{2} / \mathrm{UV}$ to reduce the brown colour of the solution.

In the majority of the triplicate well tests, growth of three of the five common saltwater algae species (Nannochloropsis gaditana, Porphyridium purpureum, and Tetraselmis chuii) on press water fractions of spent mushroom waste (champost) was found to be comparable to or better than their growth on control media. Dunaliella salina growth was relatively low. Arthrospira platensis only grew on press water when treated with $\mathrm{H}_{2} \mathrm{O}_{2}$. Overall, the results indicate that washing of champost results in a mineral rich solution suitable for growth of several (saltwater) algae. 


\section{Introduction}

For mushroom production usually a mixture of horse and chicken manure, gypsum and straw is used. After mushroom harvest a waste stream remains ( $~ 800.000$ tonnes per year), called champost (or mushroom compost waste or spent mushroom substrate/waste/compost). For every kg of mushrooms, $5 \mathrm{kgs}$ of waste is produced (Lin et al, 2014) with a dry matter content of $35 \%$ (Schlatmann and Kosse, 2018). The waste can be used for biogas production, but yields are not very high (Oei and Albert, 2008). Other options such as pyrolysis and incineration of the champost seem interesting but also complex because of its high moisture content. Another limiting factor for certain re-uses is the high electrical conductivity of the waste due to high salt concentrations. High salt concentrations $\left(\mathrm{NaCl}, \mathrm{CaCl}_{2}\right.$ ) result from the applied substrates and salt additions during the growth process. Therefore, washing of the waste leads to a better product that for example can be used as peat replacement (EC values $<1.0 \mathrm{dS} / \mathrm{m}$ ) (Blok et al, 2015). The press water contains salts and nutrients and is possibly a good medium for algae production. In this report an initial test in well plates is described with five common commercially produced saltwater algae on different fractions of the press water. These saltwater algae are used for several applications (Table 1) (Enzing et al, 2014).

Table 1 Some commercial applications/products of algae species used in the experiments (From: Enzing et al, 2014)

\begin{tabular}{ll} 
Species & Application \\
Arthrospira platensis & $\begin{array}{l}\text { Food additive } \\
\text { Phycocyanin }\end{array}$ \\
\hline Dunaliella salina & $\begin{array}{l}\beta \text {-carotene } \\
\text { Xanthophyll }\end{array}$ \\
\hline Porphyridium purpureum & Phycocyanin \\
& Food additive \\
\hline Tetraselmis chuii & Aquaculture feed \\
& Carotenoids \\
\hline Nannochloropsis gaditana & EPA \\
& Algae paste \\
& Aquaculture feed \\
& $\beta$-carotene \\
\hline
\end{tabular}

Production of the algae species on low cost safe waste streams is thus an interesting option. The press water of champost naturally has a dark brown colour, which may interfere with algal growth. DePraetere et al (2013) found that colour removal using different methods could result in a doubling of initial growth rate and a $50 \%$ increase in final biomass yield of Arthrospira platensis grown on piggery wastewater. Treatment with hydrogen peroxide $\left(\mathrm{H}_{2} \mathrm{O}_{2}\right)$ and UV resulted in $80 \%$ colour removal and had no effect on phosphate concentrations, since it oxides coloured compounds. According to Vasconcelos Fernandes et al (2015) however, the translucent brown colour of anaerobically treated blackwater does not have to be a limiting factor for algal growth, as long as algal numbers and light intensity are high enough. Weide, van der, et al (2014) also found growth on different dilutions of chicken manure digestate. They observed that with increasing digestate concentrations, algae needed more time to start growing. In the test described in this report, one fraction has been treated with hydrogen peroxide $\left(\mathrm{H}_{2} \mathrm{O}_{2}\right)$ and UV in order to decolour the medium and promote algal growth. 


\section{Materials and methods}

\section{$2.1 \quad$ Well test setup}

At ACRRES a method was developed for screening quickly the suitability of waste streams for algal growth. This method enables simultaneous quick small-scale testing of several algal species and waste streams (Huurman and van der Weide, 2015). The method results in a '+/-' result for growth plus a quantification of algal numbers and/or OD measurements. For the screening 24-well plates are used. Figure 1 shows an example of such a test.
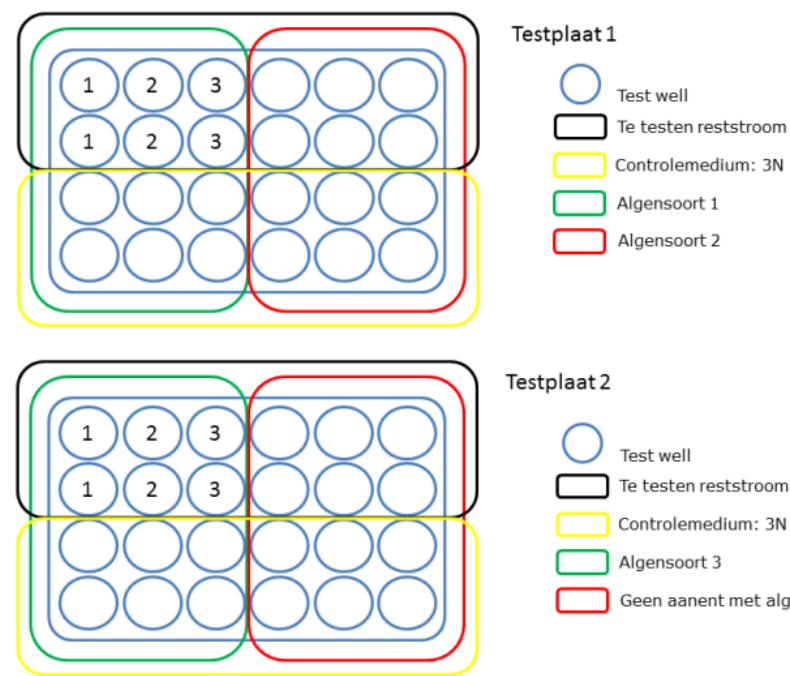

Testplaat 2

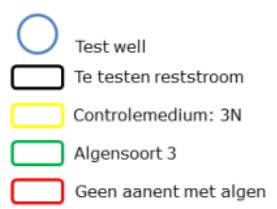

Figure 1 Example of well test for one test medium and three algae species (From: Huurman and van der Weide, 2015).

All test combinations were tested in triplicate, and some were repeated as extra controls. Four plates in total were incubated on an orbital shaker at $100 \mathrm{rpm}$ (continuously) in a climate cabinet at $20^{\circ} \mathrm{C}$ on a glass surface with white LED lightning underneath (4.3 A, 12.3 V) covered with a white paper resulting in a light intensity of $\sim 79 \mu \mathrm{mol} / \mathrm{m}^{2} / \mathrm{s} .50 \mathrm{~mL}$ of each algae stock culture was previously centrifuged for 5 minutes at $3000 \mathrm{rpm}$, the supernatant (standard medium) discarded (to remove unwanted nutrients) and the algal pellet suspended in an equal amount of half-strength artificial seawater $(15 \mathrm{~g} / \mathrm{L})$. Half-strength seawater was chosen not to disrupt the cell walls. This was repeated twice. An initial $\mathrm{OD}_{440} \mathrm{~nm}$ of 0.3 was aimed for. In each well $2.25 \mathrm{~mL}$ of press water or control medium was added plus $0.25 \mathrm{~mL}$ of precultured algae. In controls only $2.5 \mathrm{~mL}$ of press water or control medium was added. For all cell counts Bürker Türk counting chambers of $0.0025,0.04$ and $0.1 \mathrm{~mm}^{2}$ of Optik Labor (depth $0.1 \mathrm{~mm}$ ) were used depending on estimated visual algal cell density. All counts were done under a 400x (40x10) Leitz Laborlux S and a Leica DMLS microscope. After 7 days the tests were terminated. OD measurements at the end of the test were not performed as the press water was often coloured and the resulting OD would not be an accurate representation of the algae numbers.

\subsection{Press water}

Mushroom spent waste was obtained from CNC (Gennep, the Netherlands) and kept at $4{ }^{\circ} \mathrm{C}$ until use. As an indication, the composition of this waste from several sources is shown in Annex I. The DM \% was $\sim 40 \%$ and OM \% was $\sim 60 \%$ of DM. Three different types of press water were produced from the waste: 
- A: $1 \mathrm{~kg}$ of champost in a bucket was filled up to $5 \mathrm{~L}$ with demi water, stirred with a spoon and left for an hour to settle. The liquid was decanted and collected, the remaining solids pressed (by pressing a perforated bucket into a bucket with the soaked champost, thereby collecting the liquid in the upper bucket) and the press water was added to the decanted liquid. The mixed liquid was filtered over a woven mesh (Monodur PA 90n, average pore size $82.6 \mu \mathrm{m}$ ).

- $\quad B$ : The treatment for $A$ was repeated with $1 \mathrm{~kg}$ of champost and subsequently the resulting liquid was filtered over a paper filter (Schleicher \& Schuell No. 595, $180 \mathrm{~mm}$ ).

- C: $180 \mathrm{~mL}$ of $\mathrm{H}_{2} \mathrm{O}_{2}$ (hydrogen peroxide solution 34.5-36.5\%, Sigma-Aldrich) was added to $420 \mathrm{~mL}$ of liquid $B$ and left for 1 hour. The solution was subsequently placed under UV light (Sylvania Blacklight blue, F15W BLB T8 in a $1 \mathrm{~L}$ blue cap glass media bottle at $20^{\circ} \mathrm{C}$ for 3 days.

All three fractions were analysed for their composition by Eurofins (Wageningen, the Netherlands) (Annex II). The coarse and fine filtered fractions were comparable in composition, but the fraction treated with $\mathrm{H}_{2} \mathrm{O}_{2}$ contained lower concentrations of most elements, had a lower $\mathrm{EC}$ and a lower $\mathrm{pH}$. In addition, the colour of the $\mathrm{H}_{2} \mathrm{O}_{2}$ treated fraction was substantially lighter (Figure 2, Annex III). Figure 2 shows the resulting solutions and particles for $A, B$ and $C$.

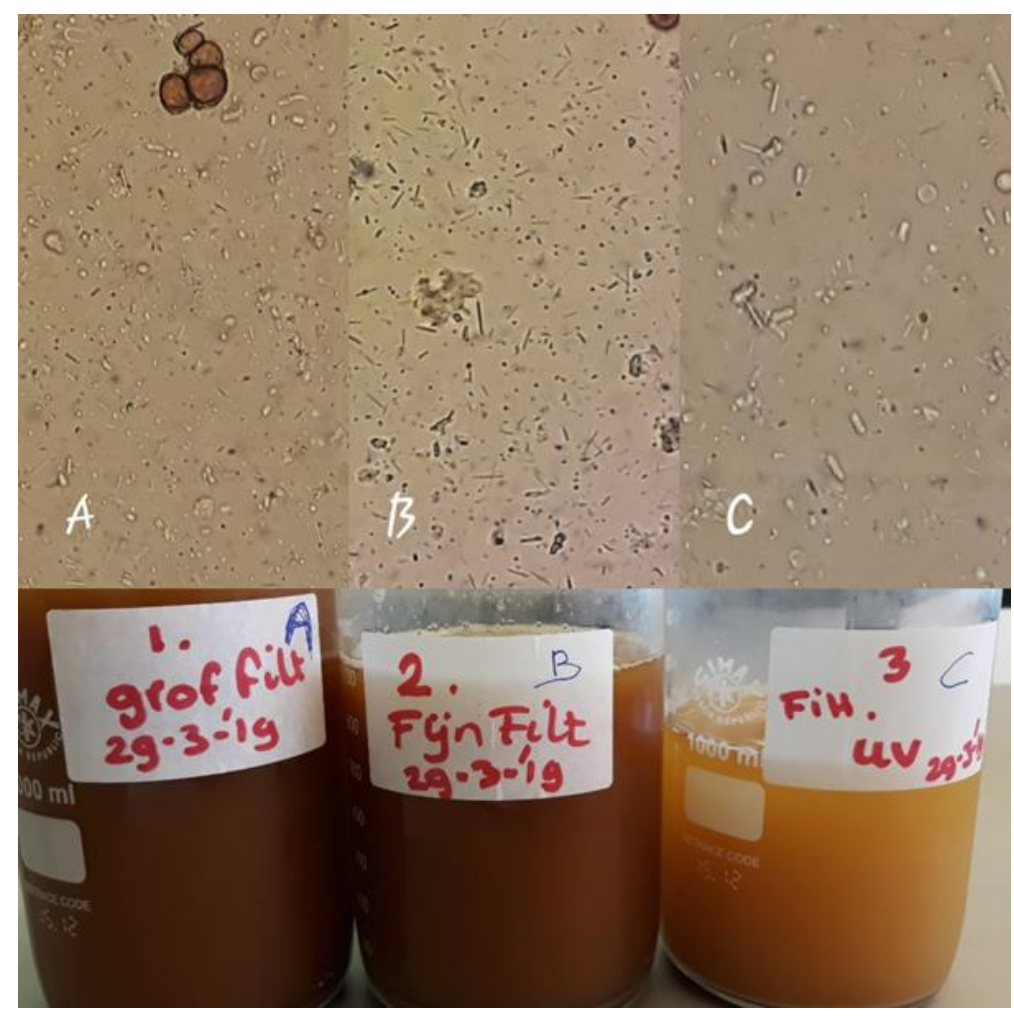

Figure 2 Solutions $A, B$ and $C$ with close-ups of the particles.

\subsection{Saltwater algae}

In a previous research growth of several saltwater algae strains was tested on salty waste streams (Elissen et al, 2018). The best growing/most common algae were selected for the current research (Table 2): A. platensis, D. salina, N. gaditana, P. purpureum and T. chuii.

Table 2 Algal strains, sources and control media used in the well tests.

\begin{tabular}{lll} 
Strain \& ACRRES code & Source & Control medium \\
Arthrospira platensis 1 & SAG 21.99 & Modified Spirulina ${ }^{1)}$ \\
\hline Dunaliella salina 2 & SAG 184.80 & f/2 (CCAP) ${ }^{2)}$ \\
\hline Nannochloropsis gaditana 3 & ACRRES lab & f/2 (CCAP) ${ }^{2)}$ \\
\hline Porphyridium purpureum 4 & SAG 1380-1d & f/2 (CCAP) ${ }^{2)}$ \\
\hline Tetraselmis chuii 8 & AF\&F (Almere, the Netherlands) & f/2 (CCAP) ${ }^{2)}$ \\
\hline
\end{tabular}

References: ${ }^{1)}$ Aiba \& Ogawa (1977), Schlösser (1994), 2) Guillard \& Ryther (1962)

Previously purchased cultures that were kept in the ACRRES lab were used for the well tests. 


\section{Results and discussion}

Figure 3 shows the growth results of different saltwater algae with press water fractions.
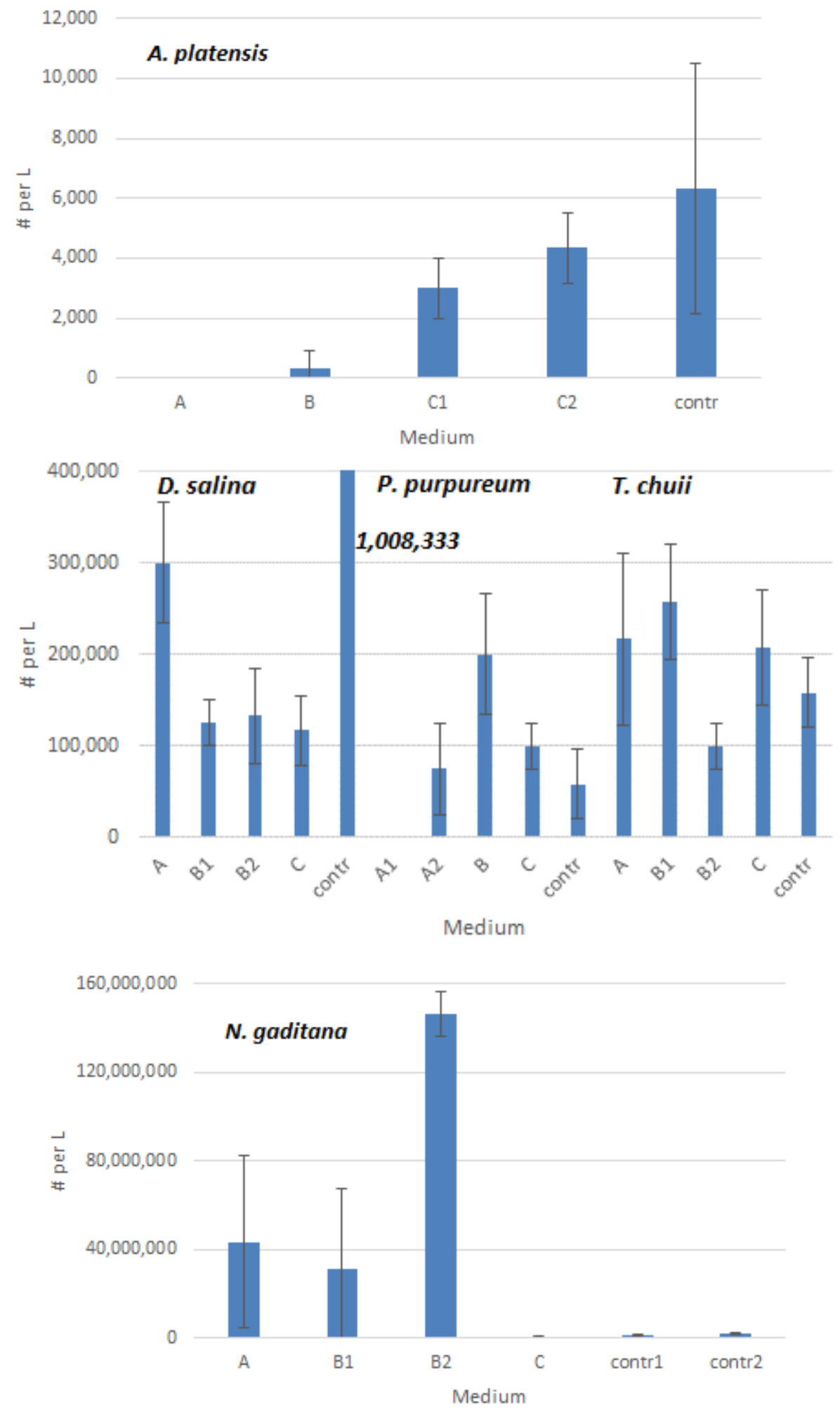

Figure 3 Growth of Arthrospira platensis (top) Dunaliella salina, Porphyridium purpureum, Tetraselmis chuii (middle) and Nannochloropsis gaditana (bottom) on different press water fractions (see Materials \& Methods) and respective control media (Table 2) ( $n=3)$. 
Numbers behind the mediums refer to repetitions of the triplicates. Separate graphs were created because of large differences in algal numbers for the different species.

Highest algae numbers were found for $N$. gaditana, followed by $D$. salina, $P$. purpureum and $T$. chuii with comparable numbers, followed by $A$. platensis with the lowest algae numbers.

Several combinations of press water fractions and saltwater algae resulted in growth in numbers comparable to growth on control media.

- A. platensis: Growth on the control medium was the best (but with a large standard deviation), followed by growth om media C, B and A. Growth in each repeated C triplicate was comparable. No algae survived in A.

- D. salina: Growth on the control medium was by far the best and was followed by media $A, B$ and C, the latter two being similar. Growth in each repeated $B$ triplicate was also comparable.

- P. purpureum: Growth on medium B was the best, followed by C, A and the control, the latter three all being very similar. Growth in the repeated A triplicates was different, as no algae survived in A1. It is not clear why there were sometimes differences in growth between two triplicates.

- T. chuii: Growth was best in B1, but this was very similar to growth in A, C and the control. Only growth in one of the repeated B triplicates (B2) was lower.

- N. gaditana: Growth was best in one of the repeated B triplicates (B2), followed by A and the repeated control triplicates. Relatively very low numbers were found in the controls and in medium $C$. The low growth in the controls could be due to the medium choice.

Table 3 shows the combinations which resulted in similar or better algae growth to control media.

Table 3 Combinations of algae with different media (see Materials \& Methods) that resulted in similar or higher growth compared to control media $(+)$ and combinations that resulted in lower numbers (-). +/- denotes triplicates resulting in different algal numbers for the same medium/algae species combination

\begin{tabular}{lccccc} 
Medium A. platensis & D. salina & P. purpureum & T. chuif & N. gaditana \\
A & - & - & $+/-$ & + & + \\
\hline B & - & - & + & + & + \\
\hline C & + & - & + & + & - \\
\hline
\end{tabular}

Press water from champost thus seems a promising medium for growth of several saltwater algae species. From the results it's not clear that (the method in this experiment used for) decolorization of these media resulted in better algae growth, except for $A$. platensis. As mentioned, decolorization has also been found to promote growth of $A$. platensis on piggery wastewater (DePraetere et al, 2013). This species may be more susceptible to lower light conditions than the other algae species that grew well on the original brownish press water fractions. Mixotrophic growth on C components in the press water in the absence of sufficient light could also have taken place in the tests were good algae growth was found.

When compared to algae numbers found in experiments with the same algae species on several 'salty' waste streams by Elissen et al (2018) only A. platensis showed overall lower numbers in the fractions and control medium used in the current test. The other algae species grew in comparable numbers. Annex III shows the well plates at the start and end of the experiment. Superficially looking, colour of the $\mathrm{H}_{2} \mathrm{O}_{2}$ treated fraction $\mathrm{C}$ changed from yellow to colourless, while wells with fractions $A$ en $B$ did not change (remained brown), except in the wells with $N$. gaditana, where the colour became more dark brown, possibly as a result of relatively high algal numbers. 


\section{Conclusions and recommendations}

In the majority of the triplicate well tests, growth of four common saltwater algae species $(N$. gaditana, P. purpureum, D. salina and T. chuii) on press water fractions of spent mushroom waste (champost) was found to be comparable to or better than their growth on control media. A. platensis only grew on press water when treated with $\mathrm{H}_{2} \mathrm{O}_{2}$. This was probably the result of higher light penetration in the liquid. The other well-growing species seemingly were not hindered by the dark colour of the press water or grew in mixotrophic mode on $\mathrm{C}$ sources in the press water. Overall the results indicate that washing of champost could lead to 1. A mineral rich solution for (saltwater) algae growth, still containing some particles, that may influence light absorbance.

2. A 'less salty' solid fraction that may be more appropriate for subsequent use of the waste as for example fertilizer or as feedstock for terrestrial insects or worms

Press water of champost could be a cheap nutrient solution for the production of several commercial algae species. It is however recommended to repeat experiments with the combinations that resulted in similar or better growth than growth on the control medium in larger test volumes. In addition, a business case should be formulated in which the extra costs for washing the champost should be included. 


\section{References}

Blok, C., P. H. B. de Visser, B. Eveleens and A. van Winkel, 2015. Reductie veen-ontginning door productie veenvervanger middels recycling Champost. Rapport GTB-1354. 78 pp.

Depraetere, O., I. Foubert and K. Muylaert, 2013. Decolorisation of piggery wastewater to stimulate the production of Arthrospira platensis. Bioresource Technology 148: $366-372$.

Elissen, H., S. Gaastra and R. van der Weide, 2018. Productie van zoutwateralgen voor toepassingen in food (en feed) Deelrapport II. Wageningen University \& Research ACRRES report PPO-750. 53 pp.

Enzing, C., M. Ploeg, M. Barbosa \& L. Sijtsma, 2014. Microalgae-based products for the food and feed sector: an outlook for Europe. Report EUR 26255 EN.

Vasconcelos Fernandes, T., R. Shrestha, Y. Sui, G. Papini, G. Zeeman, L. E. M. Vet, R. H. Wijffels and P. Lamers, 2015. Closing domestic nutrient cycles using microalgae. Environ. Sci. Technol. 2015, $49,20,12450-12456$.

Huurman, S. and R. van der Weide, 2015. Aquatische biomassa, het verwaarden van waterige reststromen op lokaal niveau. Technisch deelrapport 1: Verkenning van de mogelijkheden van reststromen en aquatische biomassa. Wageningen University \& Research ACRRES report PPO-650. $53 \mathrm{pp}$.

Lin, Y., X. Ge and Y. Li, 2014. Solid-state anaerobic co-digestion of spent mushroom substrate with yard trimmings and wheat straw for biogas production. Bioresource Technology 169: 468-474

Oei, P. and G. Albert, 2008. Alternatieve toepassingen van champost. Conceptrapportage $35 \mathrm{pp}$.

Schlatmann, S. and E. Kosse, 2018. Quickscan energie uit champost. Paddenstoelenpact, BlueTerra. Presentation June 27th 2018.

Weide, R. Y. van der, Schipperus, R. \& van Dijk, W., 2014. Algae cultivation using digestate as nutrient source: opportunities and challenges. 22nd European Biomass Conference and Exhibition, 23-26 June 2014, Hamburg, Germany: 1778-1784. 


\section{Annex 1 Compositions of champost}

Kwaliteitsonderzoek

Blgg Agro\%pertus

Compost

champost zonder dekaarde

Postbus 170

$\mathrm{NL}-6700 \mathrm{AD}$ Wageningen

T monstername: Patrick Bens: 0652002106

T klantenservice: +31 (0)88876 1010

E klantenservice@blgg.agroxpertus.nl

Uw klantnummer: 2818922

| blgg.agroxpertus.nl

CNC Grondstoffen (RHP) BV

T. v.d. Venne

Postbus 13

6590 AA GENNEP

\begin{tabular}{ll}
\hline Onderzoek & Analyse-/ordernummer: \\
& $2014903193 / 003317897$ \\
& Type monster: \\
& Champost
\end{tabular}

Datum verslag:
18-04-2014
Datum monstername:
02-04-2014

Monster genomen bij:

CNC P.H Vervoort, postbus 13

6590 AA GENNEP

champost analyse cns pve

Datum ontvangst:

07-04-2014

\begin{tabular}{|c|c|c|c|c|c|}
\hline Resultaat & & Eenheid & Resultaat & Toetswaarde & Resultaat in produkt $(g / \mathrm{kg})$ \\
\hline \multirow{24}{*}{$\begin{array}{l}\text { bepaald in pet } \\
\text { monster volgens } \\
\text { heoponer } \\
\text { vermelder normen } \\
\text { oermelde nor }\end{array}$} & Droge stof & $\mathrm{g} / \mathrm{kg}$ product & 440 & & \\
\hline & Ruw as & $\mathrm{g} / \mathrm{kg} \mathrm{ds}$ & 454 & & \\
\hline & Org. stof & $\%$ van de ds & 54,6 & 10,0 & \\
\hline & Stikstof (N) & $\mathrm{g} / \mathrm{kg} \mathrm{ds}$ & 21,5 & & 9,5 \\
\hline & Fosfor (P) & $\mathrm{g} / \mathrm{kg} \mathrm{ds}$ & 5 & & \\
\hline & Fosfaat $\left(\mathrm{P}_{2} \mathrm{O}_{5}\right)$ & $\mathrm{g} / \mathrm{kg} \mathrm{ds}$ & 11,5 & & 5,06 \\
\hline & Kalium (K) & $\mathrm{g} / \mathrm{kg} \mathrm{ds}$ & 29 & & \\
\hline & Kali $\left(\mathrm{K}_{2} \mathrm{O}\right)$ & $g^{/} / \mathrm{kg} \mathrm{ds}$ & 35 & & 15 \\
\hline & Zwavel (S) & $\mathrm{g} / \mathrm{kg} \mathrm{ds}$ & 21,8 & & 9,6 \\
\hline & Magnesium (Mg) & $\mathrm{g} / \mathrm{kg} \mathrm{ds}$ & 4,5 & & \\
\hline & Magnesia (MgO) & $\mathrm{g} / \mathrm{kg} \mathrm{ds}$ & 7.5 & & 3,3 \\
\hline & Chloride & $\mathrm{g} / \mathrm{kg} \mathrm{ds}$ & 10 & & \\
\hline & Zuurgraad $(\mathrm{pH})$ & & 5,7 & & \\
\hline & C-anorganisch & $\%$ & 0,20 & & \\
\hline & Koolzure kalk & $\%$ & 1,1 & & \\
\hline & Geleidingsvermogen & $\mathrm{mS} / \mathrm{cm} 25^{\circ} \mathrm{C}$ & 17,82 & & \\
\hline & Cadmium (Cd) & $\mathrm{mg} / \mathrm{kg} \mathrm{ds}$ & 0,31 & 1,00 & \\
\hline & Chroom (Cr) & $\mathrm{mg} / \mathrm{kg} \mathrm{ds}$ & 7.5 & 50 & \\
\hline & Koper (Cu) & $\mathrm{mg} / \mathrm{kg} \mathrm{ds}$ & 34 & 90 & \\
\hline & Kwik $(\mathrm{Hg})$ & $\mathrm{mg} / \mathrm{kg} \mathrm{ds}$ & 0,05 & 0,30 & \\
\hline & Nikkel (Ni) & $\mathrm{mg} / \mathrm{kg}$ ds & 4,2 & 20 & \\
\hline & Lood (Pb) & $\mathrm{mg} / \mathrm{kg} \mathrm{ds}$ & 6,4 & 100 & \\
\hline & Zink $(Z n)$ & $\mathrm{mg} / \mathrm{kg} \mathrm{ds}$ & 192 & 290 & \\
\hline & Arseen (As) & $\mathrm{mg} / \mathrm{kg} \mathrm{ds}$ & 1.4 & 15 & \\
\hline
\end{tabular}

Toelichting De onderzochte parameters voldoen aan de samenstellingseisen van compost zoals

vermeld in de Uitvoeringsregeling Meststoffenwet.

Contact $\&$ info Monster genomen door: Derden

Contactpersoon monstername: Patrick Bens: 0652002106

Na verzending van dit verslag wordt, indien de aard en de onderzoeksmethode van het monster dit toelaat,

het monster nog twee weken bij BLGG AgroXpertus voor u bewaard. Binnen deze tijd kunt u eventueel

reclameren en/of aanvullend onderzoek aanvragen.

Pagina: 1

Totaal aantal pagina's: 2

$903193,18-04-2014$

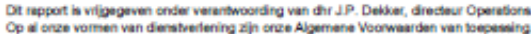

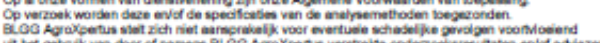

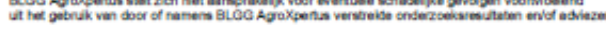

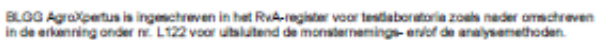




\begin{tabular}{lcr} 
& Eenheid & Resultaat \\
\hline Droge stof & G/kg product & 333 \\
\hline Org. Stof & $\%$ van de ds & 62,0 \\
\hline Fosfaat $\left(\mathrm{P}_{2} \mathrm{O}_{5}\right)$ & $\mathrm{g} / \mathrm{kg} \mathrm{ds}$ & 11,9 \\
\hline Stikstof $(\mathrm{N})$ & $\mathrm{g} / \mathrm{kg} \mathrm{ds}$ & 21,0 \\
\hline Cadmium $(\mathrm{Cd})$ & $\mathrm{mg} / \mathrm{kg} \mathrm{ds}$ & 0,29 \\
\hline Chroom $(\mathrm{Cr})$ & $\mathrm{mg} / \mathrm{kg} \mathrm{ds}$ & 7,7 \\
\hline Koper $(\mathrm{Cu})$ & $\mathrm{mg} / \mathrm{kg} \mathrm{ds}$ & 34 \\
\hline Kwik $(\mathrm{Hg})$ & $\mathrm{mg} / \mathrm{kg} \mathrm{ds}$ & 0,04 \\
\hline Nikkel $(\mathrm{Ni})$ & $\mathrm{mg} / \mathrm{kg} \mathrm{ds}$ & 4,3 \\
\hline Lood $(\mathrm{Pb})$ & $\mathrm{mg} / \mathrm{kg} \mathrm{ds}$ & 6,8 \\
\hline Zink $(\mathrm{Zn})$ & $\mathrm{mg} / \mathrm{kg} \mathrm{ds}$ & 145 \\
\hline Arseen $(\mathrm{As})$ & $\mathrm{mg} / \mathrm{kg} \mathrm{ds}$ & 1,1 \\
\hline Kali $\left(\mathrm{K}_{2} \mathrm{O}\right)$ & $\mathrm{g} / \mathrm{kg}$ & 21,5 \\
\hline Geleidingsvermogen & $\mathrm{mS} / \mathrm{cm} 25^{\circ} \mathrm{C}$ & 12,4 \\
\hline
\end{tabular}

\begin{tabular}{|c|c|c|c|c|c|c|c|c|c|}
\hline Name & compost & champost & kolen & bruinkool & kippenmest & B-hout & $\begin{array}{l}\text { RWZI } \\
\text { slib }\end{array}$ & palmpit & diermeel \\
\hline \multicolumn{10}{|l|}{ PROXANAL } \\
\hline $\begin{array}{l}\text { Moisture } \\
\text { (a.r.) }\end{array}$ & 61,20 & 63,88 & 9.85 & 58,69 & 9,29 & 9,08 & 75 & 11,01 & 2,50 \\
\hline $\begin{array}{l}\text { Fixed } \\
\text { Carbon }\end{array}$ & & & 44,12 & & 14,40 & 21,62 & 28.4 & 17,59 & 12,71 \\
\hline $\begin{array}{l}\text { Volatile } \\
\text { Matter }\end{array}$ & & & 33.62 & & 47,82 & 76,53 & & 77,28 & 63,31 \\
\hline Ash & 39,28 & 36,52 & 12,30 & 8,70 & 37,78 & 1.85 & 43 & 5.14 & 23,95 \\
\hline \multicolumn{10}{|l|}{ ULTANAL } \\
\hline Ash & 39,28 & 36,52 & 12,30 & 8,70 & 37,79 & 1,85 & 43 & 5,14 & 23,95 \\
\hline$c(d, b)$. & & & 71.05 & 61,75 & 37,38 & 50,26 & 28.4 & 48,34 & 43,07 \\
\hline$H(d . b)$. & 3.77 & 3.82 & 4.61 & 4.50 & 4,19 & 6.91 & 4.6 & 6.20 & 6,04 \\
\hline $\mathrm{N}(\mathrm{d} . \mathrm{b})$. & 2.29 & 1,90 & 1.50 & 0.60 & 3,76 & 1,03 & 3.5 & 2.62 & 2,16 \\
\hline $\mathrm{Cl}$ (d.b.) & 0.77 & 0.63 & 0.01 & 0.05 & 0,13 & 0.07 & .07 & 0.21 & 0,87 \\
\hline$S$ (d.b.) & 3,35 & 2,70 & $0.6 \theta$ & 0.39 & 0,74 & 0.00 & 0.09 & 0.26 & 1,27 \\
\hline$O$ (by diff.) & & & 9.83 & 24,02 & 15,64 & 30,88 & 18.6 & 37,23 & 15,64 \\
\hline $\begin{array}{l}\text { Stookwaarde } \\
\text { (a.r.) }\end{array}$ & 2.68 & 2.51 & 27,48 & 8,10 & 13,99 & 18.54 & $2 a_{3}$ & 19,36 & 17,27 \\
\hline \multicolumn{10}{|l|}{ Asanalyse } \\
\hline & & & & & & & & & \\
\hline \multicolumn{10}{|l|}{$\begin{array}{l}\text { macro- } \\
\text { elements }\end{array}$} \\
\hline Al & 0,31 & 0.32 & 1,71 & 0.20 & 0,18 & 0,04 & 2.7 & 0,15 & 0,28 \\
\hline $\mathrm{Ca}$ & 4,85 & 6,83 & 0.35 & 1.34 & 13,83 & 0,32 & 11.8 & 0.31 & 6,88 \\
\hline $\mathrm{Cl}$ & 0,77 & 0.63 & 0.01 & 0.85 & 0,13 & 0.07 & 0.07 & 0,21 & 0,87 \\
\hline $\mathrm{Fe}$ & 0.22 & 0,20 & 0.54 & 0,02 & 0,11 & 0,05 & 7.8 & 0,30 & 0,04 \\
\hline $\mathrm{K}$ & 3,50 & 2,62 & 0,12 & 0.23 & 3.47 & 0.16 & 0.5 & 0,63 & 0,61 \\
\hline $\mathrm{Mg}$ & 0,55 & 0,45 & 0,13 & 0,02 & 0,85 & 0,06 & 1.0 & 0,18 & 0,18 \\
\hline $\mathrm{Na}$ & 0,32 & 0.26 & 0,04 & 0.01 & 0.15 & 0.04 & 1.8 & 0,00 & 1,11 \\
\hline $\mathrm{P}$ & 0,57 & 0.47 & 0,04 & 1,84 & 2,30 & 0.08 & 5.2 & 0.62 & 4,17 \\
\hline $\mathrm{Si}$ & 4,00 & 3.55 & 3,02 & 0.07 & 0.83 & 0.20 & 10.1 & 0.39 & 0,00 \\
\hline $\mathrm{Ti}$ & 0,02 & 0.01 & 0.10 & 0.00 & 0.01 & 0.02 & 0.3 & 0.00 & 0.00 \\
\hline
\end{tabular}

Fiauur 42: Samensteling comoost. chamoost en andere aanabare brandstoffen 


\section{Annex 2 Composition of champost press water fractions}

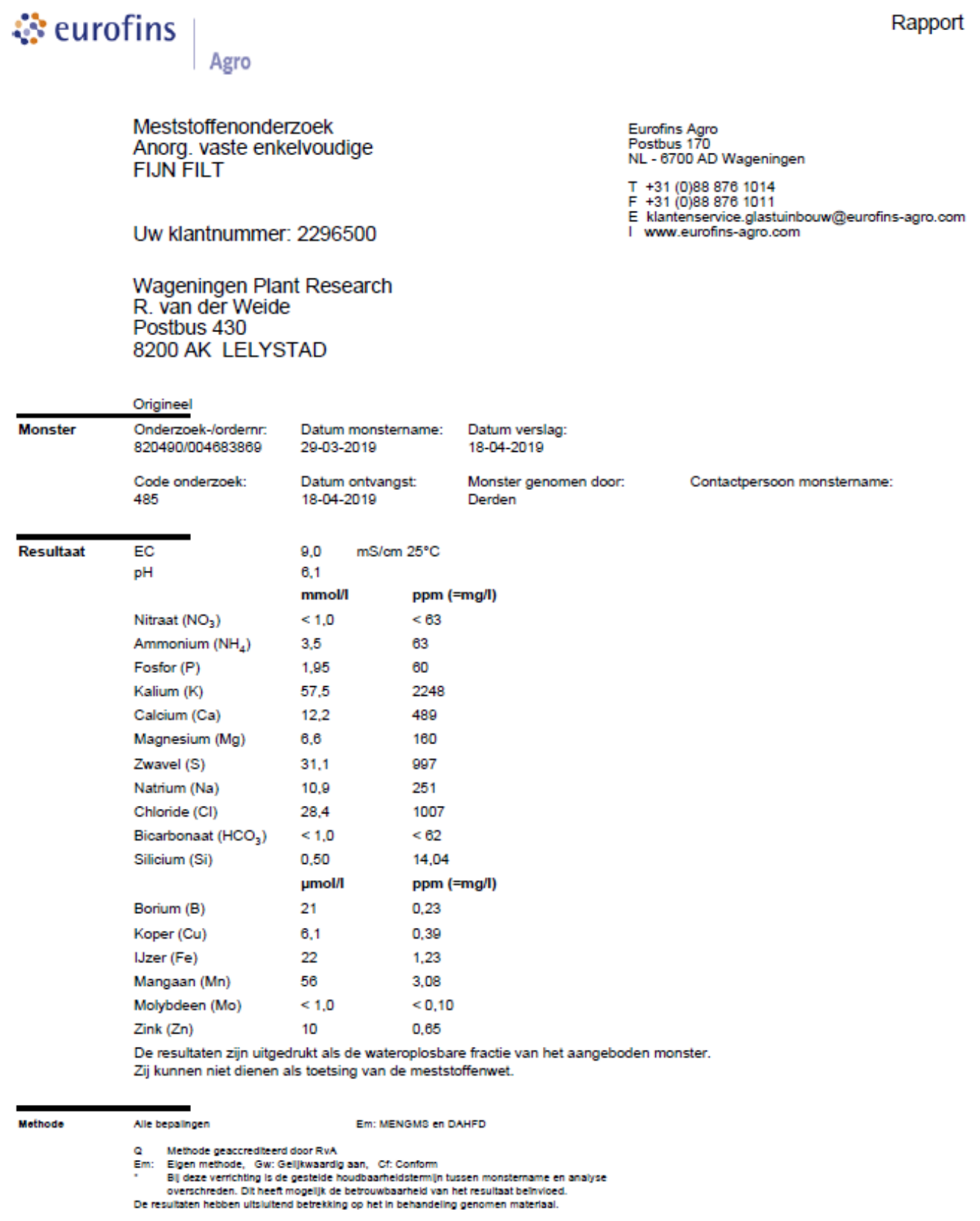

Pagina: 1

Totaal aantal pagina's: 1

Total aantal pagina's:

$820490,18-04-2019$ 
Meststoffenonderzoek

Anorg. vaste enkelvoudige

GROF FILT

Uw klantnummer: 2296500

Wageningen Plant Research

$R$. van der Weide

Postbus 430

8200 AK LELYSTAD

\begin{tabular}{|c|c|}
\hline & Origineel \\
\hline \multirow[t]{2}{*}{ Monster } & $\begin{array}{l}\text { Onderzoek-/ordernr: } \\
820489 / 004683869\end{array}$ \\
\hline & $\begin{array}{l}\text { Code onderzoek: } \\
485\end{array}$ \\
\hline \multirow[t]{18}{*}{ Resultaat } & $\mathrm{EC}$ \\
\hline & $\mathrm{pH}$ \\
\hline & Nitraat $\left(\mathrm{NO}_{3}\right)$ \\
\hline & Ammonium $\left(\mathrm{NH}_{4}\right)$ \\
\hline & Fosfor (P) \\
\hline & Kalium (K) \\
\hline & Calcium (Ca) \\
\hline & Magnesium (Mg) \\
\hline & Zwavel (S) \\
\hline & Natrium $(\mathrm{Na})$ \\
\hline & Chloride (Cl) \\
\hline & Bicarbonaat $\left(\mathrm{HCO}_{3}\right)$ \\
\hline & Silicium (Si) \\
\hline & Borium (B) \\
\hline & Koper (Cu) \\
\hline & IJzer (Fe) \\
\hline & Mangaan (Mn) \\
\hline & Molybdeen (Mo) \\
\hline
\end{tabular}

Datum monstername: Datum verslag: 29-03-2019

Datum ontvangst: 18-04-2019

18-04-2018

Monster genomen door: Derden
Eurofins Agro

Postbus 170

NL - 6700 AD Wageningen

T +31 (0)88 8761014

$F+31(0) 888761011$

E klantenservice.glastuinbouw@eurofins-agro.com

www.eurofins-agro.com
$9.3 \mathrm{mS} / \mathrm{cm} 25^{\circ} \mathrm{C}$

6,2

$\mathrm{mmol} / \mathrm{ppm}(=\mathrm{mg} / \mathrm{l})$

$<1,0<63$

$3,6 \quad 65$

$2,03 \quad 63$

$57,6 \quad 2252$

$12,3 \quad 493$

$6,7 \quad 183$

$31.2 \quad 1000$

$10,8 \quad 248$

$29.5 \quad 1048$

$<1,0<62$

$0.49 \quad 13,76$

umol/l $\quad \mathrm{ppm}(=\mathrm{mg} / \mathrm{l})$

$23 \quad 0,25$

$6,2 \quad 0,39$

$22 \quad 1,23$

$56 \quad 3,08$

$<1,0<0,10$

$10 \quad 0.65$

De resultaten zijn uitgedrukt als de wateroplosbare fractie van het aangeboden monster.

Zij kunnen niet dienen als toetsing van de meststoffenwet.

Mothode EM: MENGMS EN DAHFD

Nile bepsingen

Q. Methode gesccrediseerd door RvA

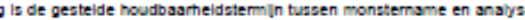

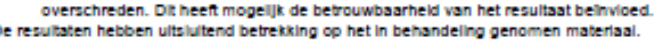

Pagina: 1

Totaal aantal pagina's: 1 
Meststoffenonderzoek

Anorg. vaste enkelvoudige

FILT + UV

Uw klantnummer: 2296500

Wageningen Plant Research

$R$. van der Weide

Postbus 430

8200 AK LELYSTAD

Origineel

\begin{tabular}{|c|c|c|c|c|c|}
\hline \multirow[t]{2}{*}{ Monster } & $\begin{array}{l}\text { Onderzoek-/ordernr: } \\
820491 / 004683869\end{array}$ & \multicolumn{2}{|c|}{$\begin{array}{l}\text { Datum monstername: } \\
\text { 29-03-2019 }\end{array}$} & \multicolumn{2}{|l|}{$\begin{array}{l}\text { Datum verslag: } \\
18-04-2019\end{array}$} \\
\hline & $\begin{array}{l}\text { Code onderzoek: } \\
485\end{array}$ & \multicolumn{2}{|c|}{$\begin{array}{l}\text { Datum ontvangst: } \\
18-04-2019\end{array}$} & \multirow[t]{3}{*}{$\begin{array}{l}\text { Monster genomen door: } \\
\text { Derden }\end{array}$} & Contactpersoon monstername: \\
\hline \multirow[t]{22}{*}{ Resultaat } & EC & 6,8 & $\mathrm{mS} / \mathrm{cm} 25^{\circ} \mathrm{C}$ & & \\
\hline & \multirow[t]{2}{*}{$\mathrm{pH}$} & 4,7 & & & \\
\hline & & $\mathrm{mmol} / \mathrm{l}$ & ppm ( & $=\mathrm{mg} / \mathrm{l})$ & \\
\hline & Nitraat $\left(\mathrm{NO}_{3}\right)$ & 2,3 & 143 & & \\
\hline & Ammonium $\left(\mathrm{NH}_{4}\right)$ & 1,8 & 32 & & \\
\hline & Fosfor $(P)$ & 2,65 & 82 & & \\
\hline & Kalium (K) & 41.4 & 1619 & & \\
\hline & Calcium $(\mathrm{Ca})$ & 9,4 & 377 & & \\
\hline & Magnesium $(\mathrm{Mg})$ & 4,9 & 119 & & \\
\hline & Zwavel (S) & 22,3 & 715 & & \\
\hline & Natrium ( $\mathrm{Na})$ & 8,4 & 193 & & \\
\hline & Chloride $(\mathrm{Cl})$ & 20,2 & 716 & & \\
\hline & Bicarbonaat $\left(\mathrm{HCO}_{3}\right)$ & $<1,0$ & $<62$ & & \\
\hline & \multirow[t]{2}{*}{ Silicium (Si) } & 0.47 & 13,20 & & \\
\hline & & $\mu \mathrm{mol} / /$ & $\mathrm{ppm}($ & $=\mathrm{mg} / \mathrm{l})$ & \\
\hline & Borium (B) & 19 & 0,21 & & \\
\hline & Koper (Cu) & 5.1 & 0,32 & & \\
\hline & IJzer (Fe) & 43 & 2,40 & & \\
\hline & Mangaan (Mn) & 47 & 2,58 & & \\
\hline & Molybdeen (Mo) & $<1,0$ & $<0,10$ & & \\
\hline & Zink $(Z n)$ & 11 & 0,72 & & \\
\hline & \multicolumn{5}{|c|}{$\begin{array}{l}\text { De resultaten zijn uitgedrukt als de wateroplosbare fractie van het aangeboden monster. } \\
\text { Zij kunnen niet dienen als toetsing van de meststoffenwet. }\end{array}$} \\
\hline \multirow[t]{2}{*}{ Mothodo } & \multicolumn{2}{|l|}{ Ale bepaingen } & \multicolumn{2}{|c|}{ Em: MENGMS en DAHFD } & \\
\hline & \multicolumn{5}{|c|}{ 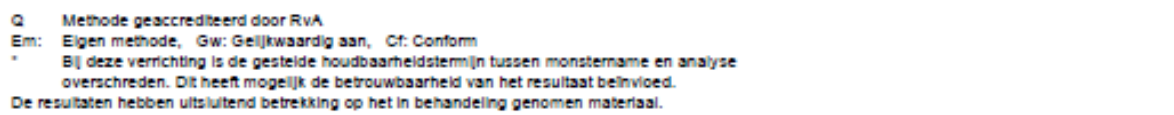 } \\
\hline
\end{tabular}

Eurofins Agro

NL - 6700 AD Wageningen

klantenservice.glastuinbouw@eurofins-agro.com

www.eurofins-agro.com
T +31 (0)88 8761014

e resulaten heboen ulta uttend betreksing op het in behandeling genomen maserisal.

Pagina: 1

Totaal aantal pagina's: 1

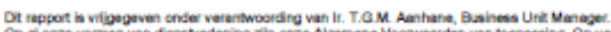

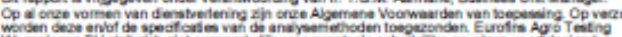

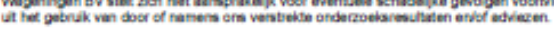

820491, 18-04-2019 


\section{Annex 3 Pictures of well plates before and after the test ( 7 days)}
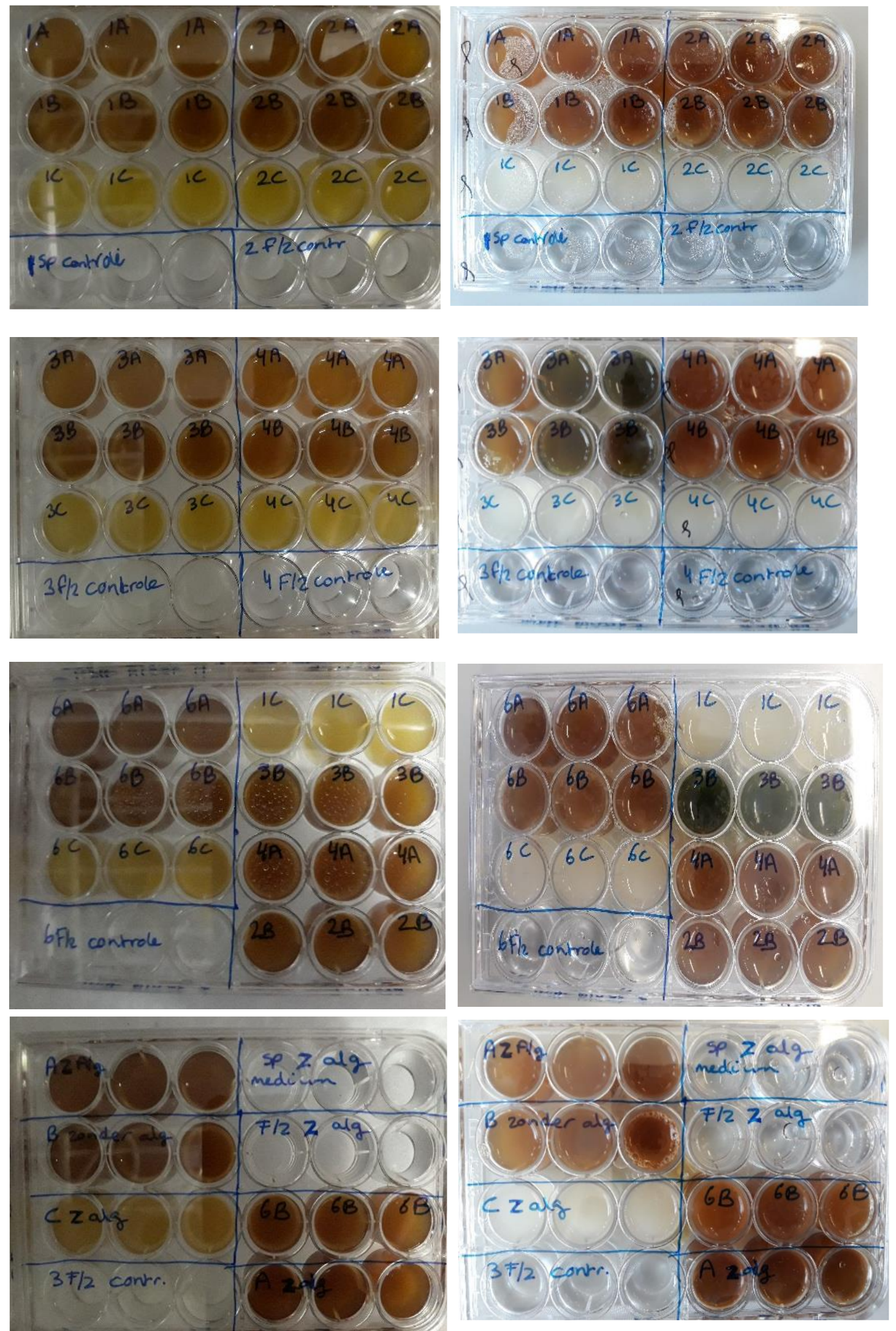


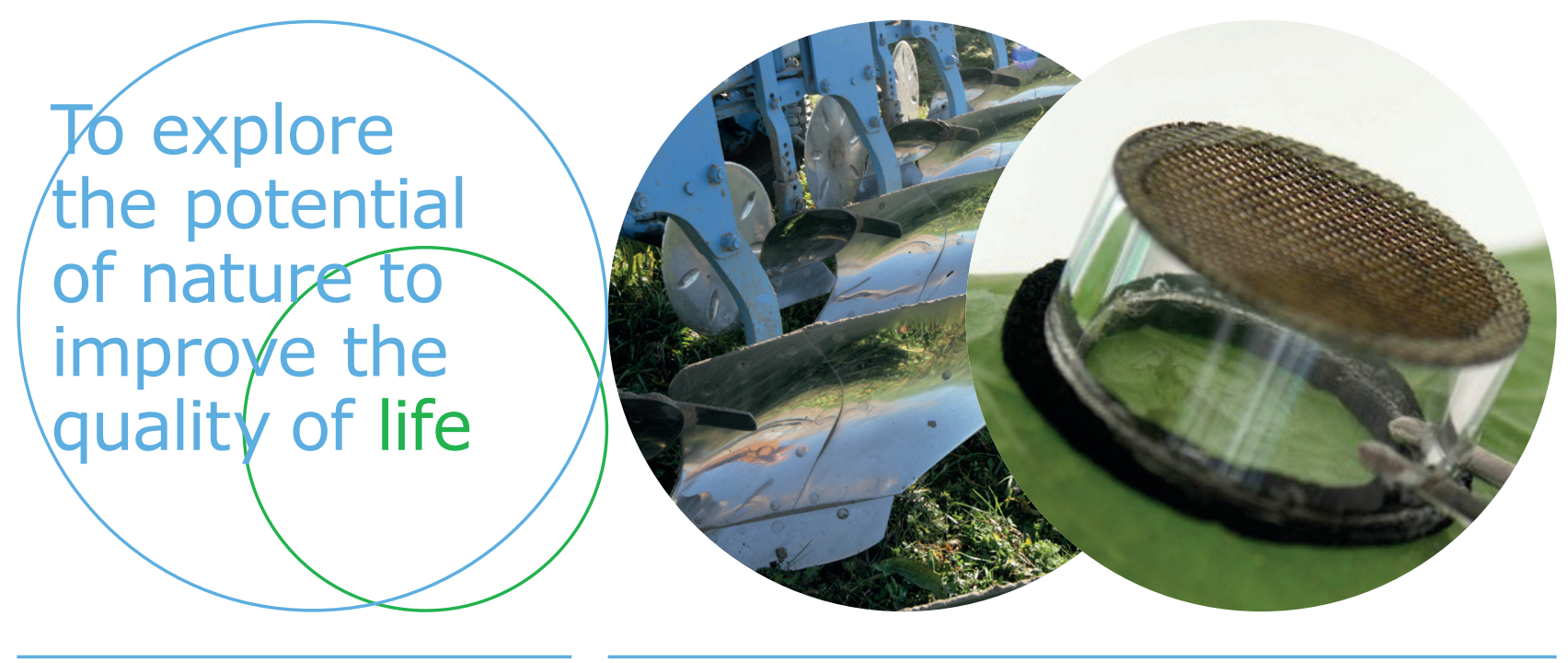

Wageningen University \& Research

\section{Open Teelten}

Edelhertweg 1

Postbus 430

8200 AK Lelystad

T (+31)3202911 11

\section{www.wur.nl/openteelten}

Rapport WPR-829
The mission of Wageningen University \& Research is "To explore the potential of nature to improve the quality of life". Under the banner Wageningen University \& Research, Wageningen University and the specialised research institutes of the Wageningen Research Foundation have joined forces in contributing to finding solutions to important questions in the domain of healthy food and living environment. With its roughly 30 branches, 6,500 employees $(5,500 \mathrm{fte})$ and 12,500 students, Wageningen University \& Research is one of the leading organisations in its domain. The unique Wageningen approach lies in its integrated approach to issues and the collaboration between different disciplines. 